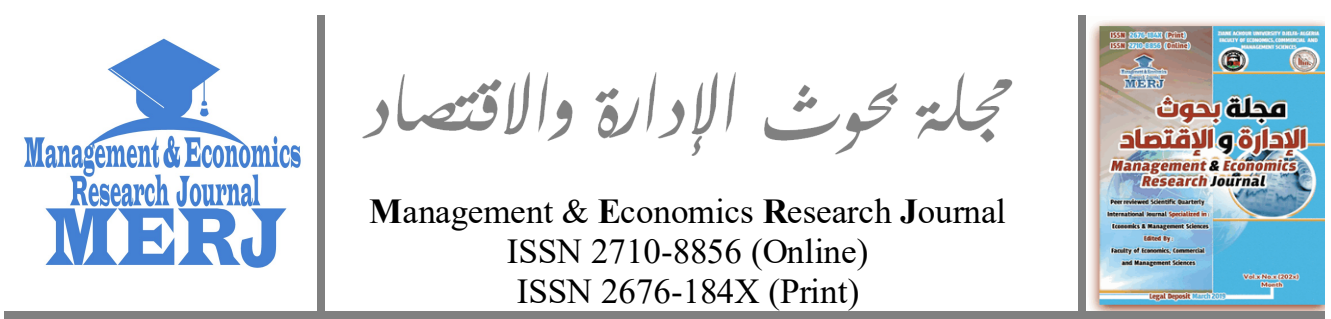

Management \& Economics Research Journal, Vol. 2 No.4 (2020), pp. 101-122

https://doi.org/10.48100/merj.v2i4.128

Check for updates

\title{
Factors Affecting the Cloud ERP: A Case Study of Learning Resources Department at Jordanian \\ Education Ministry
}

Hasan Alhanatleh ${ }^{1}$, Murat Akkaya ${ }^{2}$

${ }^{1} \mathrm{PhD}$, Education Ministry of Jordan (Jordan)

$\triangle$ Hassan hanatleh@yahoo.com

${ }^{2}$ Associate Professor, Department of Management Information Systems, Girne American

University, Kyrenia (Cyprus)

$\bowtie$ muratakkaya@gau.edu.tr

Received: 20-08-2020

Accepted: 21-09-2020

Published: 22-09-2020

\section{Abstract:}

Enterprise resource planning (ERP) systems have been used by organizations for years, whereas Cloud ERP systems gained an audience a few years ago from practitioners and academicians. As such, there is a migration from the traditional ERP to the Cloud ERP system, and employees in most organizations are accustomed to the traditional ERP system. In order to improve the efficiency and effectiveness of the Cloud ERP system used in the operation stage. Organizations must research the factors that impact users' satisfaction and managerial decision-making. There are a lot of prior studies that measured users' adoption of ERP systems using a technological acceptance model (TAM). Thus, this study also utilized the TAM model to examine the factors influencing users' adoption of Cloud ERP systems. To get the maximum value of the validity and reliability of the findings, the study was conducted in two folds: preimplementation and post-implementation. In addition, structural equation modelling was employed to reach the findings. Finally, the study identified the technology factor, employee factor, perceived usefulness and ease of use as important variables affecting Cloud ERP adoption; and as essential antecedents influencing managerial decision-making. This study is the first to employ the TAM model in the Cloud ERP area in two waves: pre-post

- Corresponding author: Education Ministry of Jordan.

[ $\triangle$ Hassan hanatleh@yahoo.com]

Faculty of Economics, Commercial \& Management

Sciences, Ziane Achour University of Djelfa, BP

3117, Djelfa - Algeria

101

www.mer-j.com

OPEN 2 ACCESS - CC) $\$$ 
implementation phases. Interestingly, the relationships between the pre-and post-implementation variables do not differ significantly.

Keywords: Cloud ERP, Cloud E-Lerrec, TAM Model, Managerial Decision Support, Technology Factor, Employee Factor, Perceived Usefulness, Perceived Ease of Use.

\section{JEL Code: M15.}

\section{Introduction}

Cloud computing is a new horizon whereby technological resources meant for computing (i.e., processing, memory, and storage) are stored at a different location rather than the user's physical location. More practically, the host or service provider provides these services to the user remotely with an internet connection (Saini, Saini, Yousif, \& Khandage, 2011). From Technicalperspective there are three models (i.e., public, private and hybrid clouds) to present the cloud services (Oracle, 2015). Moreover, to deliver cloud services, there are three (3) main approaches, namely: Software as a Service (SaaS), Infrastructure as a Service (IaaS), and Platform as a Service (PaaS), as noted by (Oliveira, Thomas, \& Espadanal, 2014; Weng, \& Hung, 2014).

Along with the emerging demand for mobility and on-demand services, the development of web-based ERP systems has become urgent research and practical agenda; that requires scholarly and practical attention (Wang et al., 2008). Besides, the incremental contribution of IS to an organization's performance is a long-term and indirect indicator of success and how effective managerial decisions were (Ruivo, Oliveira, \& Neto, 2012). Moreover, the value of IS to business can be observed through system usage (Zhu \& Kraemer, 2005), workflow enhancement and profit generation. In their influential study, Peng and Gala (2014) emphasized that there is a gap between cloud computing technology and ERP systems. A careful examination of the literature has shown that prior studies related to cloud computing were delineated as a single unit, likewise, ERP systems. According to a report prepared by Aberdeen Group in 2013. Moreover, ERP systems might be implemented from a technical perspective, but success depends on ERP users' attitudes toward the system (Kwahk \& Lee, 2008).

The present study explores an alternative way to understand and measure IS value by studying Cloud ERP in its pre-implementation and post-implementation phases. The current study developed a Cloud ERP system called (Cloud E-Learec System) for Queen Rania Center ministry of education, Jordan. Following Rajan, and Baral (2015) and Ruivo, Oliveira, and Neto's (2012) approach, we developed a model based on the technology 
acceptance model (TAM) to test the impact of the (Cloud E-Learec System) on employee performance and managerial decision-making support

\section{Theoretical framework and hypothesis}

According to Gelogo and Kim (2014), ERP systems hosted on a platform that can be accessed through the internet are known as Cloud ERP. The cloud is a host site where the ERP applications and data are stored, computing takes place, and the cloud keyword subsumes a broad set of applications and software deployment models (See figure 1). Consequently, $\mathrm{Xu}$ (2012) revealed that cloud computing services could be distributed to firms through models, namely: (1) Software as a service (SaaS); (2) Infrastructure as a service (IaaS); and (3) Platform as a service (PaaS). Figure 1 below depicts the form of ERP we have, ranging from traditional, IaaS, PaaS and SaaS ERP. In the traditional model, the firm maintains and supports all essential computing resources.
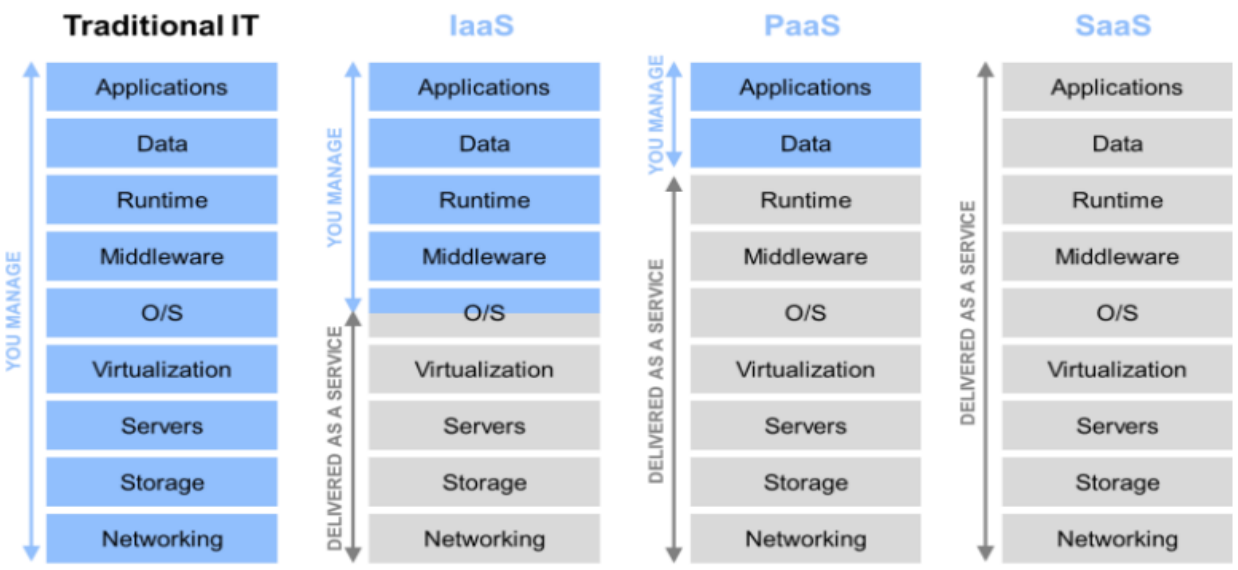

Figure 1. Cloud computing distribution models Source: (Harms \& Yamartino, 2010).

\subsection{Technology acceptance model (TAM)}

In particular, TAM was built to explain and predict user acceptance of specific types of technology. Some scholars have adopted TAM in various aspects of modern technology ranging from the use of Websites (e.g., Chang \& Chung, 2001), Web retailing (e.g., Wang, Lin \& Luarn, 2006), Web browsers (e.g., Morris \& Dillon, 1997), online purchase intentions (e.g., van-der-Heijden, Verhagen, \& Creemers, 2003). E-mail (e.g., Karahanna \& Straub, 1999), blog usage (e.g., Hsu \& Lin, 2008), Instant Messaging (e.g., Turel, Serenko, \& Bontis, 2007), mobile 
technology (e.g., Hong \& Tam, 2006) to ERP (e.g., Sternad \& Bobek, 2013). However, there is a scarcity of studies explaining the acceptance of Cloud ERP using the TAM. In this view, this study employed the TAM model to examine Cloud ERP's determinant.

\subsection{Contextual variables affecting the usage of cloud ERP}

- Technology Factor: In their influential study, Gangwar, Date and Ramaswamy (2015) noted that the technology factor has two components in the TAM framework: compatibility and complexity.

- Employee factor: Modern tertiary institution has embraced high-tech (i.e., ERP systems) due to intense competition, heavy workloads and complex tasks. Lin (2010) added that such systems are the elementary mechanisms employees use in providing technical and complicated computerized solutions.

- Perceived usefulness: Davis' TAM proposes that "perceived usefulness" and "perceived ease of use" affect "attitude toward usage"; "attitude toward usage" and "perceived usefulness" affect "intention to use"; and finally, "intention to use" affect "usage behaviour". The above-stated relationship has been validated in many research and conference papers (Hsu \& Lin, 2008).

- Perceived ease of use: According to TAM, potential users and/or users' perceived ease of use of an ERP system has a positive influence on their intention to use the system and attitude toward the use of the system. The relationship has been tested across different areas related to technology adoption. Various scholars have empirically validated the above theoretical arguments (EscobarRodriguez, Escobar-Pérez, \& Monge, 2012).

- Attitude toward usage: Prior empirical work focused more on exploring the factors that influence the success and failure of ERP systems (Santamaría-Sánchez, Núnez-Nickel, \& Gago-Rodríguez, 2010).

- Decision-making support: According to Slevin and Pinto (1987), management support refers to the willingness of top management to provide the necessary resources and autonomy to employees in any given task. Research has shown that ERP systems are complex and demand rigorous training; thus, the need for training is inevitable (Bingi, Sharma, \& Godla, 1999). Moreover, training and guidance are expected to mitigate employees' anxiety and stress concerning using the ERP system (Lee et al., 2010). 
Hasan Alhanatleh \&

Murat Akkaya
Factors Affecting the Cloud ERP: A Case Study of

Learning Resources Department at Jordanian Education

\subsection{Hypothesis and research model}

Relying on the extant literature, this study formulated the following hypotheses based on the above theoretical and empirical arguments. The hypotheses are also presented in the diagram below (See figure 2).

H1: Technology factor will significantly impact employee's perceived usefulness of Cloud E-Learec System both in the pre-and postimplementation phase.

H2: Technology factor will significantly impact employee's perceived ease of use of Cloud E-Learec System both in the pre-and postimplementation phase.

H3: Employee factor will significantly impact employee's perceived usefulness of Cloud E-Learec System both in the pre-and postimplementation phase.

H4: Employee factor will significantly impact employee's perceived ease of use of Cloud E-Learec System both in the pre-and postimplementation phase.

H5: Employees' perceived usefulness of Cloud E-Learec System will significantly impact their attitude towards use in the pre-and postimplementation phases.

H6: Employee's perceived usefulness of Cloud E-Learec System will significantly impact decision-making support in pre and postimplementation phases.

H7: Employees' perceived ease of use of the Cloud E-Learec System will significantly impact their attitude towards use in the pre-and postimplementation phases.

H8: Employee's perceived ease of use of Cloud E-Learec System will significantly impact decision-making support in pre and postimplementation phases. 


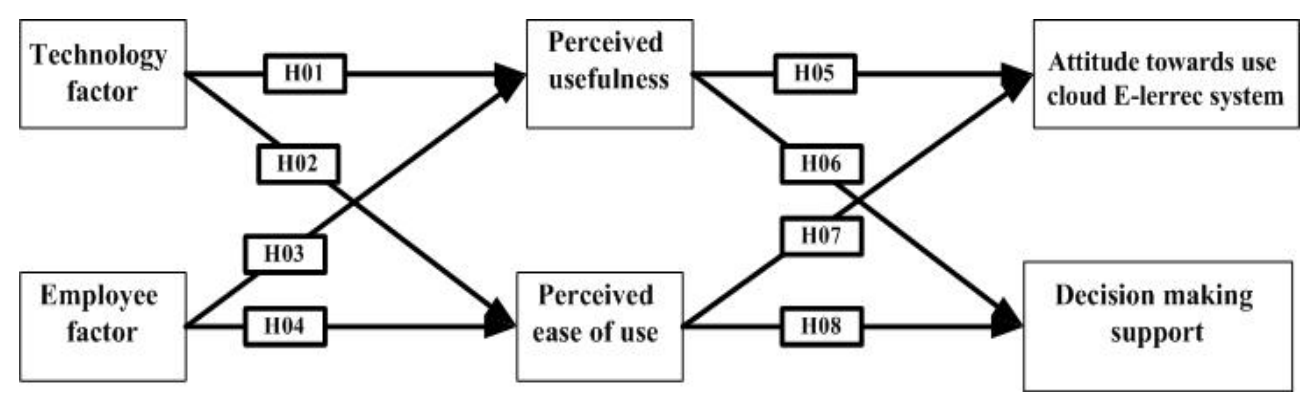

Figure 2. Conceptual model

\section{Research methodology}

\subsection{Range of study}

This study will collect primary data. Primary data is a kind of data collected from first-hand experience. This study is quantitative because the quantitative method can produce objective and reliable results, and the shortcomings of qualitative methods include low sound judgment, predictability, and certainty (Abubakar, Ilkan, \& Sahin, 2016). Accordingly, this study follows the single group pre-post test design. A two-wave test approach (pre-post implementation) will be deployed to achieve the study objectives.

\subsection{Measures and research instruments}

The response options were anchored on a 5-point scale, ranging from (1) strongly disagree to (5) strongly agree, where a higher score indicates a higher level of effecting the use of the current system.

The technology factor- was measured with 13 items adapted from the following studies (Davis, 1989; Thompson et al., 1991; Compeau \& Higgins, 1995; Brown, 2002; Rajan \& Baral, 2015). Moreover, The Employee factor was measured with eight items adopted from the following studies (Davis, 1989; Venkatesh \& Davis, 1996). Perceived usefulness -was measured with ten items adopted from the following studies (Davis, 1989; Davis, Bagozzi, \& Warshaw, 1989; Wixom \& Todd, 2005). In addition, Perceived ease of use - was measured with 12 items adapted from the following studies (Davis, Bagozzi, \& Warshaw, 1989; Venkatesh \& Davis, 1996; Brown, 2002). Next, Attitude towards use -was measured with five items adopted from the following studies (Ajzen \& Fishbein, 1980; Sumner \& Hostetler, 1999; Ngai, Poon, \& Chan,2007). As well as decision-making support - measured with five items adopted from the following studies (Al- 
Mamary, Shamsuddin, \& Aziati, 2013). Finally, Demographic variables include gender, work experience, education, and job category.

\subsection{Sample plan and size}

A convenience sampling technique was employed in this study. Researchers use this type of sampling due to the ease of access to the subjects. Probably due to proximity, ease of handling, or inexpensive, the participants are in-house employees. The initial sample consists of 500 employees voluntarily agreeing to participate in the study. Krejcie and Morgan(1970) found the table for determining the sample size of the known population. The table presents a required sample size for a specific population. Accordingly, the sample size of this study is acceptable.

\subsection{Data collection and time frame}

In the pre-test fold, data was obtained from employees working in Queen Rania Center attached to the ministry of education in Jordan. Two linguistic experts developed the survey items in English and then backtranslated them to Arabic. Five hundred questionnaires were distributed to the respondents through their respective front offices. Completed questionnaires were sealed in envelopes to make responses anonymous and confidential; this was done to decrease the potential threat of common method bias (Podsakoff et al., 2003). In the end, only 407 questionnaires were returned, resulting in an $81 \%$ response rate, and 385 responses were used for analysis due to missing data. The pre-implementation study took about six weeks in total. In the post-test fold, the same procedures applied in the pre-test fold were applied to the study. A total of 463 questionnaires were distributed. In the end, only 379 questionnaires were returned, resulting in an $82 \%$ response rate, and 369 responses were used for analysis due to missing data. The post-implementation study took about eight weeks in total.

\section{Results}

\subsection{Demographic variables}

Table 1 presents the demographic breakdown for the postimplementation and pre-implementation samples. 
Table 1. Demographic breakdown

\begin{tabular}{|c|c|c|c|c|}
\hline \multirow[b]{2}{*}{ Category } & \multicolumn{2}{|c|}{ Pre-implementation $n=385$} & \multicolumn{2}{|c|}{ Post implementation $n=369$} \\
\hline & Frequency & Percentage & Frequency & Percentage \\
\hline \multicolumn{5}{|l|}{ Gender } \\
\hline Male & 187 & 48.6 & 248 & 67.2 \\
\hline Female & 198 & 51.4 & 121 & 32.8 \\
\hline Total & 385 & 100 & 369 & 100 \\
\hline \multicolumn{5}{|l|}{ Experience } \\
\hline 5 years and less than & 66 & 17.1 & 29 & 7.9 \\
\hline $\begin{array}{l}\text { Between } 5 \text { and less than } \\
10\end{array}$ & 169 & 43.9 & 75 & 20.2 \\
\hline $\begin{array}{l}\text { Between } 10 \text { and less than } \\
15\end{array}$ & 97 & 25.2 & 104 & 28.2 \\
\hline 15 and greater than & 53 & 13.8 & 161 & 43.6 \\
\hline Total & 385 & 100 & 369 & 100 \\
\hline \multicolumn{5}{|l|}{ Qualification } \\
\hline Diploma & 169 & 43.9 & 167 & 44.4 \\
\hline B.Sc. & 90 & 23.4 & 82 & 22.2 \\
\hline High diploma & 35 & 9.1 & 67 & 18.2 \\
\hline Master & 53 & 13.8 & 41 & 11.1 \\
\hline $\mathrm{PhD}$ & 38 & 9.9 & 15 & 4.1 \\
\hline Total & 385 & 100 & 369 & 100 \\
\hline \multicolumn{5}{|l|}{ Job } \\
\hline Teacher & 77 & 20.0 & 72 & 19.5 \\
\hline Computer technician & 82 & 21.3 & 68 & 18.4 \\
\hline Science technician & 77 & 20.0 & 67 & 18.2 \\
\hline Librarian & 74 & 19.2 & 64 & 17.3 \\
\hline Administrative & 75 & 19.5 & 98 & 26.6 \\
\hline Total & 385 & 100 & 369 & 100 \\
\hline
\end{tabular}

\subsection{Confirmatory factor analysis}

All measures were subjected to confirmatory factor analysis (CFA) to support the issues of dimensionality, convergent, and discriminant validity. AMOS program was used for structural equation modeling. All the fits for the 6-item model were acceptable, as evident in Tables 2 and 3, and the one-item model was used to gauge the potential threats of CMV. The one-item model provided poorer fits when compared with the 6 item model. As such, the focal outcome shows that the tendency of CMV does not seem to exist. 
Hasan Alhanatleh \& Murat Akkaya
Factors Affecting the Cloud ERP: A Case Study of Learning Resources Department at Jordanian Education Ministry

Table 2. Goodness fit of the 6-item model

\begin{tabular}{|c|c|c|}
\hline $\begin{array}{l}\text { Goodness-of-fit indices } \\
\text { (Pre-implementation } n=385 \text { ) }\end{array}$ & $\begin{array}{l}\text { Goodness-of-fit indices } \\
\text { (post-implementation } n=369 \text { ) }\end{array}$ & Cut-off points \\
\hline $\begin{array}{l}\text { Chi-square }(\mathrm{X} 2)=4280.4 \mathrm{df} \\
=1068\end{array}$ & $\begin{array}{l}\text { Chi-square }(\mathrm{X} 2)=3574.3 \mathrm{df}= \\
1103\end{array}$ & $\mathrm{P}<0.001$ \\
\hline $\mathrm{GFI}=0.71$ & $\mathrm{GFI}=0.73$ & $\begin{array}{l}1=\text { maximum fit (Tanaka \& } \\
\text { Huba, 1985) }\end{array}$ \\
\hline $\mathrm{NFI}=0.75$ & $\mathrm{NFI}=0.78$ & $\begin{array}{l}1=\text { maximum fit (Bentler \& } \\
\text { Bonett, 1980) }\end{array}$ \\
\hline $\mathrm{CFI}=0.80$ & $\mathrm{CFI}=0.83$ & $\begin{array}{l}1=\text { maximum fit }(\text { McDonald \& } \\
\text { Marsh, 1990) }\end{array}$ \\
\hline $\mathrm{TLI}=0.79$ & $\mathrm{TLI}=0.82$ & $\begin{array}{l}1=\text { maximum fit (Bentler \& } \\
\text { Bonett, 1980) }\end{array}$ \\
\hline $\mathrm{RMR}=0.023$ & RMSEA $=0.078$ & $\begin{array}{l}\text { Values }<.06 \text { indicate a good fit } \\
\text { (Browne \& Cudeck, 1993). }\end{array}$ \\
\hline $\mathrm{CMIN} / \mathrm{DF}=3.99$ & $\mathrm{CMIN} / \mathrm{DF}=3.24$ & $\begin{array}{l}\text { Values }>1 \text { and }<5 \text { were accepted } \\
\text { (Marsh \& Hocevar, 1985) }\end{array}$ \\
\hline
\end{tabular}

Note: df, degree of freedom; GFI, goodness-of-fit indices; NF, Normed Fit Index; CFI, comparative fit index; TLI, Tucker-Lewis index; RMSEA, root mean square error of approximation; CMIN/DF, Relative Chi-square.

Table3. Goodness fit of one item model (Pre-implementation $n=385$ )

\begin{tabular}{|c|c|c|}
\hline $\begin{array}{l}\text { Goodness-of-fit indices } \\
\text { (Pre-implementation } n=385 \text { ) }\end{array}$ & $\begin{array}{l}\text { Goodness-of-fit indices } \\
\text { (post-implementation } n=369 \text { ) }\end{array}$ & Cut-off points \\
\hline $\begin{array}{l}\text { Chi-square }(\mathrm{X} 2)=9644.7 \mathrm{df} \\
=1080\end{array}$ & $\begin{array}{l}\text { Chi-square }(X 2)=8859.7, \mathrm{df}= \\
1127\end{array}$ & $\mathrm{P}<0.001$ \\
\hline $\mathrm{GFI}=0.47$ & $\mathrm{GFI}=0.45$ & $\begin{array}{l}1=\text { maximum fit (Tanaka \& } \\
\text { Huba, 1985) }\end{array}$ \\
\hline $\mathrm{NFI}=0.43$ & $\mathrm{NFI}=0.45$ & $\begin{array}{l}1=\text { maximum fit (Bentler \& } \\
\text { Bonett, 1980) }\end{array}$ \\
\hline $\mathrm{CFI}=0.46$ & $\mathrm{CFI}=0.48$ & $\begin{array}{l}1=\text { maximum fit (McDonald \& } \\
\text { Marsh, 1990) }\end{array}$ \\
\hline $\mathrm{TLI}=0.44$ & $\mathrm{TLI}=0.46$ & $\begin{array}{l}1=\text { maximum fit (Bentler \& } \\
\text { Bonett, 1980) }\end{array}$ \\
\hline $\mathrm{RMR}=0.025$ & RMSEA $=0.137$ & $\begin{array}{l}\text { Values }<.06 \text { indicate a good fit } \\
\text { (Browne \& Cudeck, 1993). }\end{array}$ \\
\hline $\mathrm{CMIN} / \mathrm{DF}=8.92$ & $\mathrm{CMIN} / \mathrm{DF}=7.86$ & $\begin{array}{l}\text { Values }>1 \text { and }<5 \text { were accepted } \\
\text { (Marsh \& Hocevar, 1985) }\end{array}$ \\
\hline
\end{tabular}

Note: df, degree of freedom; GFI, goodness-of-fit indices; NF, Normed Fit Index; CFI, comparative fit index; TLI, Tucker-Lewis index; RMSEA, root mean square error of approximation; CMIN/DF, Relative Chi-square.

Next, the mean and standard deviation of the measures used were generated to evaluate the normality and skewness of the responses. The data seems to have a normal distribution based on the mean and standard deviation values, as depicted in the table below. Next, the psychometric properties of the scale items were evaluated. Some items from pre and postconstruction were deleted due to poor loadings and cross-loading in our CFA. The retained item loadings exceeded .50, as suggested by (Hair et al., 
2006). Cronbach's alphas were all above the benchmark of .60; similarly, $\mathrm{CR}$ and AVE were also above the benchmark of .70 and .50, as recommended by (Hair et al., 2006), except for perceived ease of use which was below .50. Fornell and Larcker (1981) suggested that if AVE is less than 0.5 , but the $\mathrm{CR}$ is higher than 0.6 . The convergent validity of the construct is still adequate. Based on this concluded that this does not seem to affect the constructs' convergent validity. For further detail, see Tables 4 and 5. As a final remark, the current outcome shows convergent and discriminant validity of the study constructs.

Table 4. Mean and Standard deviation of the measures (pre-post-implementation)

\begin{tabular}{|c|c|c|c|c|c|}
\hline \multicolumn{3}{|c|}{ Pre-implementation } & \multicolumn{3}{|c|}{ Post-implementation } \\
\hline Scale items & S.D & & Scale items & Mean & S.D \\
\hline Technology factor & & & Technology factor & & \\
\hline Item 1 & 4.55 & 0.51 & Item 1 & 4.54 & 0.52 \\
\hline Item 2 & 4.51 & 0.60 & Item 2 & 4.51 & 0.61 \\
\hline Item 3 & 4.59 & 0.50 & Item 3 & 4.60 & 0.50 \\
\hline Item 4 & 4.42 & 0.66 & Item 5 & 4.60 & 0.50 \\
\hline Item 5 & 4.60 & 0.50 & Item 6 & 4.52 & 0.53 \\
\hline Item 6 & 4.53 & 0.53 & Item 7 & 4.53 & 0.57 \\
\hline Item 7 & 4.55 & 0.55 & Item 8 & 4.52 & 0.60 \\
\hline Item 8 & 4.52 & 0.64 & Item 9 & 4.60 & 0.52 \\
\hline Item 9 & 4.62 & 0.52 & Item 10 & 4.64 & 0.51 \\
\hline Item 10 & 4.67 & 0.50 & Item 11 & 4.64 & 0.50 \\
\hline Item 11 & 4.64 & 0.52 & Item 12 & 4.60 & 0.50 \\
\hline Item 12 & 4.62 & 0.49 & Item 13 & 4.59 & 0.51 \\
\hline Employee factor & & & Employee factor & & \\
\hline Item 1 & 4.63 & 0.57 & Item 1 & 4.63 & 0.46 \\
\hline Item 2 & 4.69 & 0.47 & Item 2 & 4.68 & 0.47 \\
\hline Item 3 & 4.67 & 0.54 & Item 3 & 4.69 & 0.47 \\
\hline Item 4 & 4.70 & 0.53 & Item 4 & 4.62 & 0.46 \\
\hline Item 5 & 4.61 & 0.58 & Item 5 & 4.67 & 0.47 \\
\hline Item 6 & 4.67 & 0.56 & Item 6 & 4.73 & 0.47 \\
\hline Item 7 & 4.73 & 0.46 & Perceived usefulness & & \\
\hline Perceived usefulness & & & Item 1 & 4.60 & 0.49 \\
\hline Item 1 & 4.59 & 0.50 & Item 2 & 4.57 & 0.51 \\
\hline Item 2 & 4.57 & 0.50 & Item 3 & 4.63 & 0.52 \\
\hline Item 3 & 4.62 & 0.55 & Item 4 & 4.61 & 0.49 \\
\hline Item 4 & 4.62 & 0.54 & Item 5 & 4.64 & 0.51 \\
\hline Item 5 & 4.67 & 0.51 & Item 6 & 4.65 & 0.50 \\
\hline Item 6 & 4.61 & 0.59 & Item 7 & 4.63 & 0.55 \\
\hline Item 7 & 4.67 & 0.47 & Item 8 & 4.66 & 0.49 \\
\hline Item 8 & 4.67 & 0.51 & Item 9 & 4.68 & 0.50 \\
\hline Item 9 & 4.68 & 0.48 & Item 10 & 4.66 & 0.48 \\
\hline Perceived ease of use & & & Perceived Ease of use & & \\
\hline Item 1 & 4.74 & 0.45 & Item 1 & 4.74 & 0.45 \\
\hline Item 2 & 4.75 & 0.43 & Item 2 & 4.76 & 0.42 \\
\hline Item 3 & 4.68 & 0.52 & Item 3 & 4.69 & 0.52 \\
\hline Item 4 & 4.67 & 0.54 & Item 4 & 4.68 & 0.53 \\
\hline Item 5 & 4.67 & 0.56 & Item 5 & 4.71 & 0.53 \\
\hline
\end{tabular}




\begin{tabular}{|c|c|c|c|c|c|}
\hline $\begin{array}{l}\text { Hasan Alhanatleh \& } \\
\text { Murat Akkaya }\end{array}$ & \multicolumn{5}{|c|}{$\begin{array}{c}\text { Factors Affecting the Cloud ERP: A Case Study of } \\
\text { Learning Resources Department at Jordanian Education } \\
\text { Ministry }\end{array}$} \\
\hline Item 6 & 4.75 & 0.47 & Item 6 & 4.75 & 0.47 \\
\hline Item 7 & 4.72 & 0.49 & Item 7 & 4.71 & 0.48 \\
\hline Item 8 & 4.71 & 0.45 & Item 8 & 4.72 & 0.44 \\
\hline Item 9 & 4.75 & 0.45 & Item 9 & 4.75 & 0.44 \\
\hline Item 10 & 4.75 & 0.47 & Item 10 & 4.74 & 0.47 \\
\hline Item 11 & 4.77 & 0.44 & Item 11 & 4.75 & 0.46 \\
\hline Item 12 & 4.76 & 0.45 & Item 12 & 4.76 & 0.44 \\
\hline Attitude towards use & & & Attitude & & \\
\hline Item 1 & 4.67 & 0.51 & Item 1 & 4.70 & 0.48 \\
\hline Item 2 & 4.70 & 0.47 & Item 2 & 4.71 & 0.49 \\
\hline Item 3 & 4.66 & 0.55 & Item 3 & 4.65 & 0.56 \\
\hline Item 4 & 4.62 & 0.53 & Item 4 & 4.64 & 0.50 \\
\hline Decision-making Support & & & Item 5 & 4.67 & 0.50 \\
\hline Item 1 & 4.70 & 0.47 & Decision & & \\
\hline Item 2 & 4.67 & 0.48 & Item 1 & 4.72 & 0.46 \\
\hline Item 3 & 4.74 & 0.46 & Item 2 & 4.71 & 0.48 \\
\hline Item 4 & 4.64 & 0.50 & Item 3 & 4.76 & 0.45 \\
\hline & & & Item 4 & 4.82 & 0.38 \\
\hline
\end{tabular}

Table 5. Psychometrics properties of the measures (pre-post implementation)

\begin{tabular}{lcccccc}
\hline \multicolumn{2}{c}{ Pre-implementation } & \multicolumn{5}{c}{ Post-implementation } \\
\hline Items & $\alpha$ & CR & AVE & $\alpha$ & CR & AVE \\
& & & & & & \\
Technology factor & 0.91 & 0.92 & 0.50 & 0.92 & 0.92 & 0.50 \\
Employee factor & 0.92 & 0.90 & 0.57 & 0.92 & 0.91 & 0.64 \\
Perceived usefulness & 0.93 & 0.92 & 0.57 & 0.92 & 0.93 & 0.56 \\
Perceived ease of use & 0.92 & 0.92 & 0.49 & 0.93 & 0.93 & 0.50 \\
Attitude towards use & 0.89 & 0.87 & 0.65 & 0.91 & 0.91 & 0.68 \\
Decision-making support & 0.85 & 0.86 & 0.62 & 0.83 & 0.83 & 0.55 \\
\hline
\end{tabular}

Notes: CR, construct reliability; AVE, average variance extracted; $\alpha$, Cronbach's alpha; Measure of sampling adequacy (pre-implementation) $=0.90$; Bartletts: the test of sphericity (preimplementation $)=16257.3$, df (pre-implementation $)=1128$; KMO Measure of sampling adequacy $($ post-implementation $)=0.91$, Bartletts: the test of sphericity $($ post-implementation $)=16122.6, \mathrm{df}$ (post- implementation $=1326, \mathrm{p}=0.000$.

In the pre-implementation and post-implementation phases, the $\mathrm{KMO}$ measure of sampling adequacy is equal to 0.90 and 0.70 , respectively, above the cutoff point of 0.70 and 0.91 , similarly; Bartletts: the est of Sphericity is equal to 16257.3 with a degree of freedom equals 1128 and 16122.6 with a degree of freedom equals 1326 respectively, and the sample p-value was significant. This gave us the ground and confidence to carry on with our analyses.

\subsection{Structural equation model}

The figures below represent the structural equation model retrieved from the AMOS program; it also shows the explained variance and the strength of the relationship. 


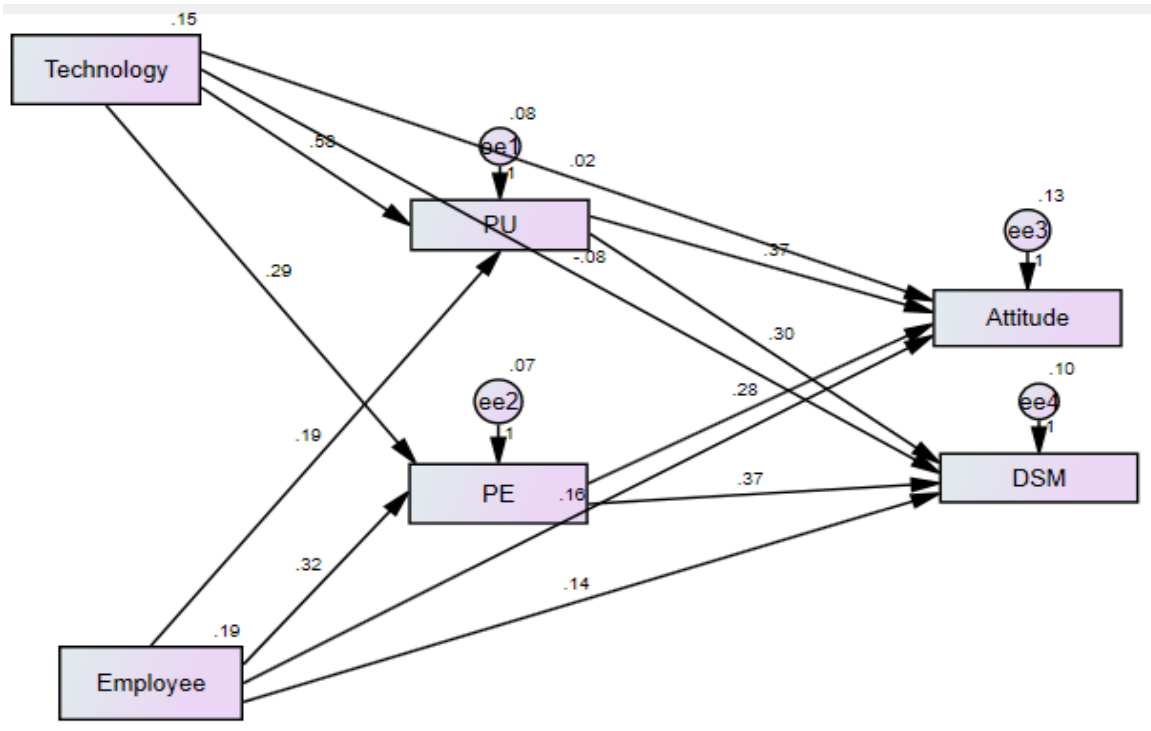

Figure 3. SEM of the research (Pre-implementation)

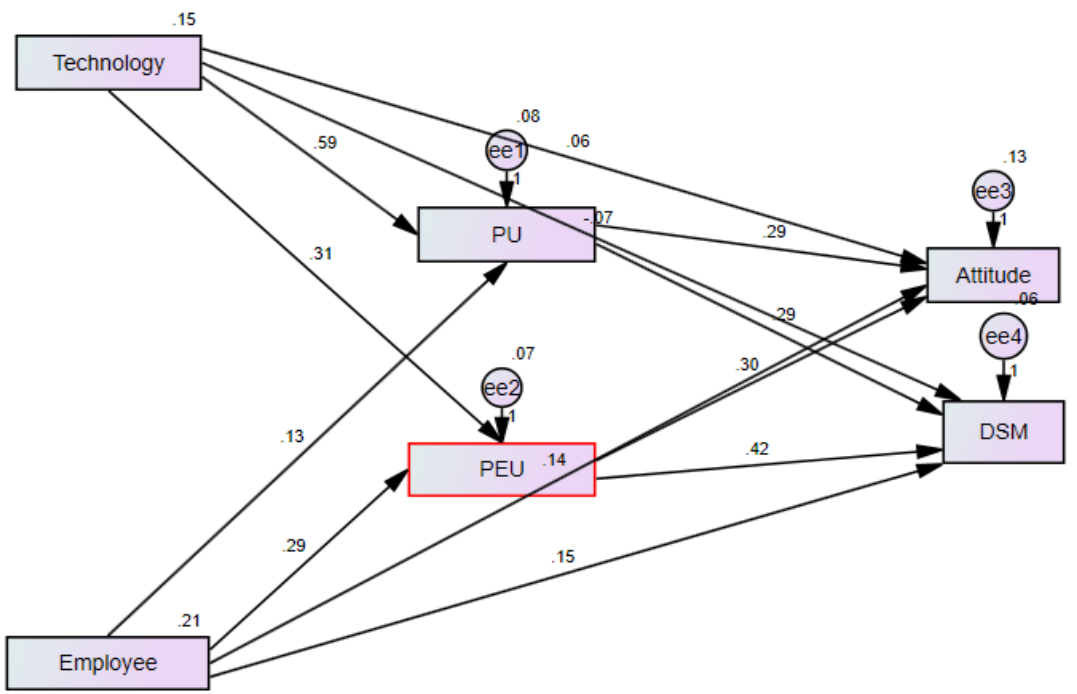

Figure 4. SEM of the research (post-implementation)

Table 6 shows the results of the hypotheses for pre and post- Table 6 shows the results of the hypotheses for pre and post-implementation. In addition, table 7 represents the regression coefficients for pre and postimplementation. The coefficients and t-statistics were used to derive whether a difference exists between the outcome in the pre-implementation 
phase and the post-implementation phase. The table shows that the strength of the relationship between the proposed variables in both the preimplementation and post-implementation phases does not differ significantly. This does provide additional robustness for the current findings in two folds. In addition, recent research by Abdinnour, \& Saeed (2015) shows that studies utilizing pre-implementation and postimplementation approaches can use varying sample sizes.

Table 6. Test hypothesis

\begin{tabular}{|c|c|c|c|c|c|c|c|c|c|}
\hline \multicolumn{5}{|c|}{ Pre-implementation } & \multicolumn{5}{|c|}{ Post-implementation } \\
\hline Hypothesis & $\mathrm{B}$ & $\mathrm{p}$ & $\mathrm{R}^{2}$ & Result & Hypothesis & $\mathrm{B}$ & $\mathrm{P}$ & $\mathrm{R}^{2}$ & result \\
\hline $\mathrm{H}_{1}$ & 0.585 & 0.000 & 0.47 & $\begin{array}{l}\text { gained } \\
\text { empirical } \\
\text { support }\end{array}$ & $\mathrm{H} 1$ & 0.591 & 0.000 & 0.44 & $\begin{array}{l}\text { gained } \\
\text { empirical } \\
\text { support }\end{array}$ \\
\hline $\mathrm{H}_{2}$ & 0.290 & 0.000 & 0.31 & $\begin{array}{l}\text { gained } \\
\text { empirical } \\
\text { support }\end{array}$ & $\mathrm{H} 2$ & 0.313 & 0.000 & 0.28 & $\begin{array}{l}\text { gained } \\
\text { empirical } \\
\text { support }\end{array}$ \\
\hline $\mathrm{H}_{3}$ & 0.193 & 0.000 & 0.29 & $\begin{array}{l}\text { gained } \\
\text { empirical } \\
\text { support }\end{array}$ & $\mathrm{H} 3$ & 0.127 & 0.002 & 0.20 & $\begin{array}{l}\text { gained } \\
\text { empirical } \\
\text { support }\end{array}$ \\
\hline $\mathrm{H}_{4}$ & 0.322 & 0.000 & 0.35 & $\begin{array}{l}\text { gained } \\
\text { empirical } \\
\text { support }\end{array}$ & $\mathrm{H} 4$ & 0.288 & 0.000 & 0.30 & $\begin{array}{l}\text { gained } \\
\text { empirical } \\
\text { support }\end{array}$ \\
\hline $\mathrm{H}_{5}$ & 0.372 & 0.000 & 0.31 & $\begin{array}{l}\text { gained } \\
\text { empirical } \\
\text { support }\end{array}$ & H5 & 0.287 & 0.000 & 0.25 & $\begin{array}{l}\text { gained } \\
\text { empirical } \\
\text { support }\end{array}$ \\
\hline $\mathrm{H}_{6}$ & 0.298 & 0.000 & 0.28 & $\begin{array}{l}\text { gained } \\
\text { empirical } \\
\text { support }\end{array}$ & H6 & 0.290 & 0.000 & 0.34 & $\begin{array}{l}\text { gained } \\
\text { empirical } \\
\text { support }\end{array}$ \\
\hline $\mathrm{H}_{7}$ & 0.282 & 0.000 & 0.27 & $\begin{array}{l}\text { gained } \\
\text { empirical } \\
\text { support }\end{array}$ & H7 & 0.300 & 0.000 & 0.25 & $\begin{array}{l}\text { gained } \\
\text { empirical } \\
\text { support }\end{array}$ \\
\hline $\mathrm{H}_{8}$ & 0.372 & 0.000 & 0.31 & $\begin{array}{l}\text { gained } \\
\text { empirical } \\
\text { support }\end{array}$ & H8 & 0.423 & 0.000 & 0.43 & $\begin{array}{l}\text { gained } \\
\text { empirical } \\
\text { support }\end{array}$ \\
\hline
\end{tabular}


Table 7. Comparison of pre and post-implementation samples

\begin{tabular}{llll}
\hline Independent Variables & Dependent Variables & $\beta(\mathrm{t})$ Pre Sample & $\beta(\mathrm{t})$ Post Sample \\
\hline Technology factor & Perceived usefulness & $0.585(15.474)$ & $0.591(15.513)$ \\
Technology factor & Perceived ease of use & $0.290(8.254)$ & $0.313(8.627)$ \\
Employee factor & Perceived usefulness & $0.193(5.729)$ & $0.127(3.884)$ \\
Employee factor & Perceived ease of use & $0.322(10.297)$ & $0.288(9.250)$ \\
Perceived usefulness & Attitude towards use & $0.372(5.929)$ & $0.287(4.376)$ \\
Perceived usefulness & $\begin{array}{l}\text { Decision-making } \\
\text { support }\end{array}$ & $0.298(5.364)$ & $0.290(6.303)$ \\
Perceived ease of use & Attitude towards use & $0.282(4.163)$ & $0.300(4.344)$ \\
Perceived ease of use & $\begin{array}{l}\text { Decision-making } \\
\text { support }\end{array}$ & $0.372(6.213)$ & $0.423(8.3745)$ \\
\hline
\end{tabular}

Notes: ${ }^{*}$ Significant at the $\mathrm{p}<0.05$ level (two-tailed); ${ }^{* *}$ significant at the $\mathrm{p}<0.01$ level (two-tailed).

We bootstrapped the model to produce a bias-corrected confidence interval for the standardized parameter estimate as recommended by (Preacher \& Hayes, 2004; Shrout \& Bolger, 2002), utilizing a validation sample of $(n=2,000)$. Based on the outcome, we concluded that there is a partial mediation between the two constructs through perceived ease of use. Finally, bootstrapping analysis suggests that our sample size is not affecting the current results.

\section{Discussion and conclusion}

This research aims to validate a model that attempts to understand the determinants of users' attitudes toward the use and managerial decision support of Cloud ERP in a tertiary organizational context. More specifically, Queen Rania Center is attached to the ministry of education in Jordan. According to Lee, Lee, Olson, and Chung (2010), the key importance of ERP systems is their ability to reduce the time required to complete business operations, facilitate information sharing, and provide the organization with an efficient and proper work atmosphere that most employees wish to have (Sternad \& Bobek, 2013). This research aimed to improve the understanding of how the influence of technological and employee factors can increase the degree of the attitude of Cloud ERP users toward the ERP system; and how managerial decision support can be enhanced. This work extended previous TAM research into the Cloud ERP realm.

First, as theorized by TAM technology factor was found to have a positive and significant association with the perceived usefulness of Cloud E- Lerrec in both studies (pre and post-implementation phase), this is associated with (Davis, 1989; Stockdale \& Standing, 2006). Furthermore, the technology factor was found to have a positive and significant association with the perceived ease of use of Cloud E-lerres in both studies (pre and post-implementation phase), as noted by prior studies (MacGregor, 
\& Vrazalic, 2005; Poon \& Swatman, 1999). Our findings show that the employee factor has a positive and significant association with the perceived usefulness of Cloud E-lerres in both studies (pre and post-implementation phases). Prior studies have documented a similar relationship (Davis, 1989; Saadé \& Bahli, 2005; Martins, Oliveira, \& Popovič, 2014). Additionally, the employee factor was found to have a positive and significant association with the perceived ease of use of Cloud E-lerres in both studies (pre and post-implementation phases). Prior studies have documented similar relationships (Davis, 1989; Hartwick \& Barki, 1994; Iivari \& Ervasti, 1994). Further, perceived usefulness significantly influences users' attitudes towards using Cloud E-lerres in both studies (pre and post-implementation phases). This notion has also been supported empirically by (Braun, 2013). Additionally, perceived usefulness significantly influences managerial decision support associated with the Cloud E-lerres system in both studies (pre and post-implementation phases). This is agreed with (Hwang, Chang, Chen \& Wu, 2008), (Park, Zo, Ciganek, \& Lim, 2011), (And al-Mamary, Shamsuddin, \& Aziati, 2013). This study also uncovers that perceived ease of use has a positive and noticeable impact on users' attitudes towards using Cloud E-lerres in both studies (pre and post-implementation phases). This is documented in (Davis, 1989) Nah, Tan, \& Teh, 2004; Dembla et al., 2007 (Stockdale \& Standing, 2006). Finally, perceived ease of use significantly influences managerial decision support associated with the Cloud E-lerres system in both studies (pre and post-implementation phases).

The study sample size, both in the pre and post-implementation phase, is small and does not reveal detailed information on how Cloud ERP affects decision-makers' behaviours. This is expected to have more effect and use over time. Future research on how Cloud ERP technology will influence managers' decision-making would be welcome and insightful. The study's cross-sectional design might lead to casual interference among the study variables; as such, the current outcome should be viewed cautiously. Future studies should adopt a longitudinal approach and a large sample size to validate the findings. The findings in this study are associated with a single country and a single sector.

\section{References}

Abubakar, A. M., Ilkan, M., \& Sahin, P. (2016). eWOM, eReferral and gender in the virtual community. Marketing Intelligence \& Planning, 34(5), 692-710. http://dx.doi.org/10.1108/mip-05-2015-0090

Abdinnour, S., \& Saeed, K (2015). User perceptions towards an ERP system: Comparing the post-implementation phase to the pre- 
implementation phase. Journal of Enterprise Information Management, 28(2), 243 - 259.

Al-Mamary, Y. H., Shamsuddin, A., \& Aziati, N. (2013). The Impact of Management Information Systems Adoption in Managerial Decision Making: A Review. Management Information Systems, 8(4), 10-17.

Ajzen, I., \& Fishbein, M. (1980). Understanding attitudes and predicting social behavior. Englewood Cliffs, N.J.: Prentice-Hall.

Bharadwaj, A. S. (2000). A resource-based perspective on information technology capability and firm performance: an empirical investigation. MIS Quarterly, 24, 169-196.

Brown, I. T. J. (2002). Individual \& technological factors affecting perceived ease of use of web-based learning technologies in a developing country. The Electronic Journal on Information Systems in Developing Countries, 9(5), 1-15.

Braun, M.T. (2013). Obstacles to social networking website use among older adults. Computers in Human Behavior, 29(3), 673-680. http://dx.doi.org/10.1016/j.chb.2012.12.004

Bingi, P., Sharma, M. K., \& Godla, J. K. (1999). Critical issues affecting an ERP implementation. Information Systems Management, 16, 7-14.

Chuang, T., Nakatani, K., \& Chen, T. T. (2015). An exploratory study of the expected business value of cloud computing. Issues in Information Systems, 16(4), 37-47.

Chen, C., Liang, W., \& Hsu, H. (2015). A cloud computing platform for ERP applications. Applied Soft Computing, 27, 127-136.

Chang, M. K., \& Chung, W. (2001). Determinants of the intention to use Internet/WWW at work: A confirmatory study. Information \& Management, 39(1), 1-14

Compeau, D. R., \& Higgins, C. A. (1995). Computer self-efficacy: development of a measure and initial test. MIS Quarterly, 19(2), 189-211

Dembla, P., Palvia, P., \& Krishnan, B. (2007). Understanding the adoption of web enabled transaction processing by small businesses. Journal of Electronic Commerce Research, 8(1), 1-16.

Davis, F. D. (1989). Perceived usefulness, perceived ease of use, and user acceptance of information technology. MIS Quarterly, 13(3), 319340.

Davis, F., Bagozzi, R., \& Warshaw, P. (1989). User acceptance of computer technology: a comparison of two theoretical models. Management Science, 35(8), 982-1003. 
Hasan Alhanatleh \& Murat Akkaya
Factors Affecting the Cloud ERP: A Case Study of Learning Resources Department at Jordanian Education Ministry

Escobar-Rodriguez, T., Escobar-Pérez, B., \& Monge-Lozano, P. (2012). Technical and organisational aspects in enterprise resource planning systems implementation: lessons from a Spanish public hospital. Enterprise Information Systems, 8(5), 533-562. http://dx.doi.org/10.1080/17517575.2012.713122

Fornell, C., Larcker, D., (1981). Evaluating structural equation models with unobservable and measurement error. Journal of Marketing Research, 18(1), 39-50.

Gelogo, Y. E., \& Kim, H. (2014). Smart mobile ERP system on the cloud framework. Advanced Science and Technology Letters, 49, 112-115

Gangwar, H., Date, H., \& Ramaswamy, R. (2015). Understanding determinants of cloud computing adoption using an integrated TAMTOE model. Journal of Enterprise Information Management, 28(1), $107-130$.

Hsu, C. L., \& Lin, C. C. (2008). Acceptance of blog usage: The roles of technology acceptance, social influence and knowledge sharing motivation. Information \& Management, 45, 65-74.

Hong, S. J., \& Tam, K. Y. (2006). Understanding the adoption of multipurpose information appliances: The case of mobile data services. Information Systems Research, 17(2), 162-179.

Hair Jr., J. F., Black, W. C., Babin, B. J., \& Anderson, R. E. (2010). Multivariate data analysis: A global perspective, $7^{\text {th }}$ ed. Pearson Prentice Hall, Upper Saddle River, N.

Hwang, H., Chang, I., Chen, F., \& Wu, S. (2008). Investigation of the application of KMS for diseases classifications: A study in a Taiwanese hospital. Expert Systems with Applications, 34(1), 725733.

Hartwick, J., \& Barki, H. (1994). Explaining the role of user participation in information system use. Management Science, 40(4), 440-465.

Iivari, J., \& Ervasti, I. (1994). User information satisfaction: IS implementability and effectiveness, Information and Management, 27(4), 205-220.

Kwahk, K. Y., \& Lee, J. N., (2008). The role of readiness for change in ERP implementation: Theoretical bases and empirical validation, Information \& Management, 45(7), 474-481.

Karahanna, E., \& Straub, D. W. (1999). The psychological origins of perceived usefulness and ease-of-use. Information \& Management, $35,237-250$. 
Krejcie, R.V. \& Morgan, D.W. (1970). Determining sample size for research activities. Educational and psychological measurement,30, 607-610.

Lin, H. (2010). An investigation into the effects of IS quality and top management support on ERP system usage, Total Quality Management \& Business Excellence, 21(3), 335-349, http://dx.doi.org/10.1080/14783360903561761

Lee, D. H., Lee, S. M., Olson, D. L., \& Chung, S. H., (2010). The effect of organizational support on ERP implementation, Industrial Management \& Data Systems, 110 (1-2), 269-283.

MacGregor, R., \& Vrazalic, L. (2005). A basic model of electronic commerce adoption barriers: a study of regional small businesses in Sweden and Australia. Journal of Small Business and Enterprise Development, 12(4), 510-527.

Morris, M. G., \& Dillon, A. (1997). How user perceptions influence software use. IEEE Software, 14(4), 58-65.

Martins, C., Oliveira, T., \& Popovič, A. (2014). Understanding the Internet banking adoption: A unified theory of acceptance and use of technology and perceived risk application. International Journal of Information Management, 34(1), 1-13, http://dx.doi.org/10.1016/j.ijinfomgt.2013.06.002

Ngai, E. W. T., Poon, J. K. L., \& Chan, Y. H. C. (2007). Empirical examination of the adoption of WebCT using TAM. Computers \& Education, $48(2)$ 250-267, http://dx.doi.org/10.1016/j.compedu.2004.11.007

Oliveira, T, Thomas, M., \& Espadanal, M. (2014). Assessing the determinants of cloud computing adoption: An analysis of the manufacturing and services sectors, Information \& Management,51, 497-510.

Olhager, J., \& Selldin, E. (2003). Enterprise resource planning survey of Swedish manufacturing firms. European Journal of Operational Research, 146, 365-73.

Peng G. C., \& Gala, G. J. (2014). Cloud ERP: A new dilemma to modern organizations? Journal of Computer Information Systems, 54(4), 2230.

Podsakoff, P. M, MacKenzie, S. B., Lee, J. Y., \& Podsakoff, N. P. (2003). Common method biases in behavioral research: a critical review of the literature and/recommended remedies.Journal of Applied Psychology, 88, 879-903. 
Hasan Alhanatleh \& Murat Akkaya
Factors Affecting the Cloud ERP: A Case Study of Learning Resources Department at Jordanian Education Ministry

Preacher, K. J., \& Hayes, A. F., (2004). SPSS and SAS procedures for estimating indirect effects in simple mediation models. Behavior Research Methods Instruments Computer, 36(4), 717-731

Ruivo, P., Oliveira, T., \& Neto, M. (2012). ERP use and value: Portuguese and Spanish SMEs. Industrial Management \& Data Systems, 112(7), 1008-1025.

Rajan, C. A., \& Baral, R. (2015). Adoption of ERP system: An empirical study of factors influencing the usage of ERP and its impact on end user, IIMB Management Review,27(2),105-117. http://dx.doi.org/10.1016/j.iimb.2015.04.008

Saini, S.L., Saini, D.K., Yousif, J.H. and Khandage, S.V. (2011). Cloud computing and enterprise resource planning systems. Proceedings of the World Congress on Engineering, London, U.K, 1,681-684.

Santamaría-Sánchez, L., Núnez-Nickel, M., \& Gago-Rodríguez, S. (2010). The role played by interdependences in ERP implementations: An empirical analysis of critical factors that minimize elapsed time. Information and Management, 47(2), 87-95.

Slevin, D. P., \& Pinto, J. K. (1987). Balancing strategy and tactics in project implementation. Sloan Management Review,29, 33-44.

Sumner, M., \& Hostetler, D. (1999). Factors influence the adoption of technology in teaching. Journal of Computer Information Systems, 40(1), 81-87.

Stockdale, R., \& Standing, C. (2006). A classification model to support SME e-commerce adoption initiatives. Journal of Small Business and Enterprise Development, 13(3), 381-394.

Saadé, R., \& Bahli, B. (2005). The impact of cognitive absorption on perceived usefulness and perceived ease of use in on-line learning: an extension of the technology acceptance model. Information \& Management,42(2), 317-327.

Turel, O., Serenko, A., \& Bontis, N. (2007). User acceptance of wireless short messaging services: Deconstructing perceived value. Information \& Management, 44, 63-73.

Thompson, R. L., Higgins, C. A., \& Howell, J. M. (1991). Personal computing: toward a conceptual model of utilization. MIS Quarterly, 15(1), 125-143.

Van der Heijden, H., Verhagen, T., \& Creemers, M. (2003). Understanding online purchase intentions: contributions from technology and trust perspectives. European Journal of Information Systems, 12, 41-48. 
Venkatesh, V. (2000). Determinants of perceived ease of use: integrating control, intrinsic motivation, and emotion into the technology acceptance model. Information Systems Research, 11(4), 342-365.

Wixom, B.H., \& Todd, P.A. (2005). A theoretical integration of user satisfaction and technology acceptance. Information Systems Research, 16, 85-102.

Weng, F., \& Hung, M. C. (2014). Competition and Challenge on Adopting Cloud ERP.International Journal of Innovation, Management and Technology, 5(4), 309-313.

Wang, T. L., Su, C. H., Tsai, P. Y., Liang, T. Y., \& Wu, W. H. (2008). Development of a Grid ERP architecture: integration of grid computing and enterprise resources planning application, in $4^{\text {th }}$ International Conference on Wireless Communications, Networking and Mobile Computing, 1-4.

Wang, I. S., Lin, H. H., \& Luarn, P. (2006). Predicting consumer intention to use mobile service. Information Systems Journal, 16, 157-179

$\mathrm{Xu}, \mathrm{X}$. (2012). From cloud computing to cloud manufacturing. Robotics and Computer-Integrated Manufacturing, 28(1), 75-86. http://dx.doi.org/10.1016/j.rcim.2011.07.002

Z Zhu, K., \& Kraemer, K.L. (2005). Post-adoption variations in usage and value of e-business by organizations: cross-country evidence from the retail industry. Information Systems Research, 16, 61-84. 


\section{Appendix}

\section{Technology factor}

Steps to complete a task in the Cloud E-Learec system follow a logical sequence.

Performing an operation in the Cloud E-Learec system led to a predicted result.

Screens of the Cloud E-Learec system were organized.

The Cloud E-Learec system was characterized by rapid response even at peak times.

The cloud E-learning resources system provided relevant information for work.

The Cloud E-Learec system presented the information in an appropriate format.

The information from the Cloud E-Learec system was up-to-date enough for my purposes.

The reliability of output information from the cloud electronic learning resources system was high.

The Cloud E-Learec system provided the information when I need in time.

The Cloud E-Learec system had a modern-looking interface.

The Cloud E-Learec system provided the right solution to my request.

The Cloud E-Learec system gave me prompt service.

The Cloud E-Learec system had a good interface to meet my needs and labour.

\section{Employee factor}

I have experience using handled devices (Laptops, tablets, smartphones...).

I have experience to use the internet.

The Cloud E-Learec system is exactly what I need.

I am sure it was the right thing to adopt the Cloud E-Learec system.

Owning the Cloud E-Learec system has been a good experience.

I am satisfied with the performance of The Cloud E-Learec system service.

I am satisfied with the decision to work over the Cloud E-Learec system.

I am pretty satisfied with the cloud E-learning resources system which has been chosen.

\section{perceived usefulness}

Using the Cloud E-Learec system improved the quality of the work I do.

Using the Cloud E-Learec system gave me greater control over the activities in my work.

The Cloud E-Learec system enabled me to accomplish tasks more quickly.

The Cloud E-Learec system supported critical aspects.

The Cloud E-Learec system increased my productivity.

The Cloud E-Learec system improved my job performance.

The Cloud E-Learec system allowed me to accomplish more work than would otherwise be possible.

The Cloud E-Learec system enhanced my effectiveness on the job.

The Cloud E-Learec system made it easier to do my job.

Overall, the Cloud E-Learec system was useful in my job.

\section{perceived Ease of use}

Overall, I found the Cloud E-Learec system interface easy to use.

My interaction with the Cloud E-Learec system was clear and understandable.

The Cloud E-Learec system required the fewest steps possible to accomplish what I want to do with it.

Using the cloud E-Learec system is effortless.

I could use the Cloud E-Learec system without written instructions

I did not notice any inconsistencies when I use the Cloud E-Learec system.

I could recover from mistakes quickly and easily over the Cloud E-Learec system.

I could use the Cloud E-Learec system successfully every time. 
Learning to use the Cloud E-Learec system interface was easy for me.

It was easy for me to become skilful at using the Cloud E-Learec system interface.

I found the Cloud E-Learec system interface to be flexible to interact with.

I easily remembered how to use the Cloud E-Learec system.

\section{Attitude towards use}

I had a generally favourable attitude toward using the Cloud E-Learec system.

I believed it was a good idea to use the Cloud E-Learec system for my work.

I liked the idea of using the Cloud E-Learec system.

Using the Cloud E-Learec system provided me with a lot of enjoyment.

Overall, I enjoyed using the Cloud E-Learec system.

\section{Decision-making Support}

The Cloud E-Learec system helped me to make various decisions in the time when I need such as daily decisions making, weekly decisions making, monthly decisions making and annual decisions making.

The nature of information in the cloud E-learning resources system supported the decisionmaking.

The cloud E-learning resources system provided the reports which assist decision-making. The cloud E-learning resources system allowed me to make the right decisions that relate to my work.

Overall, the cloud E-learning resources system improved the decision-making process.

(C) 2020 the Author(s). This is an open access article distributed under the terms of Creative Commons AttributionNon Commercial License (CC BY-NC 4.0) which permits use, distribution and reproduction in any medium, provided the original work is properly cited and is not used for commercial purposes.

\section{Recommended citation:}

Alhanatleh, H., \& Akkaya, M. (2020). Factors Affecting the Cloud ERP: A Case Study of Learning Resources Department at Jordanian Education Ministry. Management \& Economics Research Journal, 2(4), 101-122. https://mer-j.com/merj/index.php/merj/article/view/128 